\title{
Human Rights Due Diligence toward the Corporation of Fishery Sector in Indonesia
}

\author{
Indra Rahmatullah \\ Syarif Hidayatullah \\ State Islamic University \\ Jakarta, Indonesia \\ indra.rahmatullah@uinjkt.ac.id.
}

\begin{abstract}
Indonesia is a maritime country where maritime itself becomes an important sector in improving the economy. This expectation needs to be balanced with the protection of the state to every business actor either corporation or to the workers so that their rights and obligations are guaranteed. One of the protections from the state is to provide guidance on Human Rights Due Diligence to companies engaged in fisheries sector. It has very important role in the fishery industry and occupies strategic and important function to guarantee the rights of workers to avoid human rights violations as occurred in the Benjina case where there was forced labor and human trafficking as an evidence of exploitation of workers. Therefore, it is the obligation of the companies to conduct Human Rights Due Diligence to ensure that no modern exploitation and slavery takes place. However, not all sectors of the fishery industry are fully concerned and realize this. This research aims to provide an overview of the legal policy of the regulation of Human Rights Due Diligence and its practice for companies in the fisheries sector using the method of normative-empirical law research so that this study is expected to provide a broader discourse that the protection of human rights is not only a state obligation but also corporations.
\end{abstract}

Keywords-Human Rights; Due Diligence and Corporation

\section{INTRODUCTION}

The obligation to protect, respect and fulfill the human rights was initially imposed on the state. The state is traditionally regarded as the main duty-bearer in relation of human rights because the state is given superior strength and capacity compared to other actors. Therefore, the concept of responsiblity of human rights are still dominated by statecentric views.

However, in the last few years, discussion about nonstate actors who are also burdened with responsibility of human rights has been discussed widely. It can be interpreted that the traditional view has been challenged as the current human rights regime has significant transformation in the last few decades. Non-state actors have also been burdened in relation of human rights, especially to those which have rivalled the economic and organizational strength of the state so as to allow them intervene in the realization of human rights.
John Ruggie introduced to the world about the Guiding Principles on Business and Human Rights, known as the Ruggie Principles (later known as the UN Guidelines on Business and Human Rights). There are three pillars of the framework of the Ruggie Principles, namely: 1. The state's obligation to protect human rights; 2 . Responsibility of the Company to respect human rights; 3 . The need for bigger access to recovery for business victims (Institute for Policy Reseach and Advocacy, 2014: 1).

The relation of the corporation to respect human rights can be seen sociologically such as in the case of the collapse of Rana Plaza in Bangladesh that caused the deaths of 1,100 people and the fire that occurred at the Kentex Philippines Plant which caused 50 deaths. In fact, report from the National Commission on Human Rights states that up to the present, there have been 1,012 reports from the public to the National Commission on Human Rights concerning alleged human rights abuses by corporations in Indonesia. One of the case in the fisheries sector is the disclosure of the practice of labor slavery in Benjina-Maluku. This is one proof of human rights violations by Thai companies affiliated with Indonesian company PT. Pusaka Benjina Resources (PBR).

In fact there are 1,342 fishermen in Benjina and Ambon who are victims of trafficking. The violations done by the corporation in addition to human trafficking are child labor, human and goods smuggling, and illegal fuel transactions. Human rights violation against fishermen is one of the most frequent violations in the fisheries sector in Indonesia besides illegal immigrants, money laundering, tax evasion, corruption and illicit drug abuse (Mas Achmad Santosa, 2017: 5).

Even on the ASEAN scale, Indonesia is one of the countries with the most victims. International Organization for Migrants (IOM) released that Indonesia ranked as the second most vulnerable to human rights violations in the period of 2011-2015 with the following details: Myanmar 1.328 victims, Indonesia 283 victims, Cambodia 299 victims, Thailand 78 victims, and Laos 13 victims (International Organization for Migrants, 2017: 7).

Moreover, the incident can not only be found in Benjina-Maluku but also in some other areas in Indonesia such as Lhokseumawe, Meulaboh, Belawan, Tanjung Balai, DKI Jakarta, Tanjung Pindang, Tarempa, Pontianak, Bau-Bau, Ambon, Kupang and Merauke (International Organization for 
Migrants, 2017: 8). This is a warning for the Government to give serious attention to human rights violations of fishermen conducted by corporations.

The future challenges faced by Indonesia will be more intricate due to various economic integrations such as foreign investment flows, trade, tourism, capital and foreign services. This condition will lead to conflicts between the community and corporations. The Indonesian government must prepare to face this phenomenon.

Human rights violations are allegedly committed by the business sector, both at the national and international levels and have triggered the urgency that countries should agree to create guidelines for the implementation of business and human rights sector at regional and national levels. Indonesia is one of the countries that provides the guidance for the corporation to conduct the Human Rights due diligence in every action done by the corporation.

The function of human rights due diligence is to identify, prevent, mitigate and account for the impacts of corporate action on human rights (United Nations, 2011). Thus, prior to making any corporate actions, corporations can thoroughly analyze whether the impact of such actions either in the process of opening business, production or service are against human rights (August Reinisch, 2004: 37-92).

\section{THE CORRELATION OF BusinesS AND HUMAN RightS}

Imposing human rights responsibilities on non-state actors-particularly businesses-has been the subject of extensive debate since the 1970s (if not before). For the most part, these debates have centred on three important questions: To whom is a business enterprise responsible? What should a business enterprise be responsible for? What type of responsibility and obligation (if any) does a business enterprise have with regard to respecting human rights? These are all legitimate questions, which were finally tackled by the United Nations' "Protect, Respect and Remedy: a Framework for Business and Human Rights"(2008)2 and "Guiding Principles on Business and Human Rights: Implementing the United Nations 'Protect, Respect and Remedy' Framework (Human Rights Council, 2011: A/HRC/17/31).

The Guiding Principles on Business and Human Rights marks a turning point for business actors, states, and civil society particularly in three different contexts: First, it provides answers to the long debate on whether or not a business has human rights responsibilities. The Guiding Principles rests on three pillars: Protect, Respect, and Remedy. The Duty to Protect (Pillar One) refers to the obligation of a state to protect against human rights abuses within its territory and/or jurisdiction by third parties, including business enterprises, through effective appropriate policies, regulation, and adjudication (Human Rights Counil, 2011: A/HRC/17/31).. The Responsibility to Respect (Pillar Two) requires all business actors to act with due diligence to avoid infringing on the rights of others and to address adverse human rights impacts with which they are involved (Human Rights Council, 2011: 11-24). Access to Remedy (Pillar Three) ensures greater access by victims to effective remedy, both judicial and non-judicial (Human Rights Council, 2011: 11-24).
Second, the Guiding Principles confirm that the responsibility of business to respect human rights does not shift human rights responsibilities away from the state, and does not confer on business the same duties to protect, respect, promote and fulfil human rights as states. The Framework and Guiding Principles are clear on the distinct duties and responsibilities that befall states and business.

Third, the Guiding Principles provide a universallyaccepted and agreed upon expectation of what companies should do regarding human rights. That is to say that there is an expectation that business should respect human rights (do no harm) and that business needs to have in place appropriate policies, due diligence processes and remedial mechanisms to manage risk to human rights. Moreover, the Guiding Principles apply to all business regardless of size, sector, ownership, or operating context. However, size and other characteristics may, in practice, influence the kinds of approaches businesses take to meet their human rights responsibility.

While In the context of human rights, it is clear that Indonesia has committed itself to respect and protect human rights (Human Rights Council, 2012: A/HRC/21/7), and that the government continues to take various actions and enact reforms to realize this commitment. This can be seen in the support offered by its institutional framework (including the performance of the judicial, legislative, and executive institutions), the enactment of laws respecting human rights (Human Rghts Council, 2012: A/HRC/WG.6/13/IDN/1), ratification of several major international human rights instruments (ILO Conventions (No. 19, 27, 29, 45, 69, 81, 87, $88,98,100,105,106,111,120,138,144,182, \& 185)$, and the adoption of the National Action Plan on Human Rights.

The protection of human rights has been legally recognised as a constitutional right in Articles 27, 28A-28J, and 29 of the 1945 Indonesian Constitution. They are further elaborated in the 1999 Human Rights Law and more than 20 other laws which directly and indirectly implicate human rights.

Article 1 (6) of the Human Rights Law confirms that human rights violations can be committed by "individuals or groups of individuals, including the state apparatus." "Groups of individuals" arguably also includes corporations and other business entities, and this interpretation has been applied by the National Commission on Human Rights (Komnas HAM) in dealing with cases involving human rights violations by non-state actors, including businesses.

A more direct reference to the human rights obligations of private actors is found in the 2008 Law No. 40 on the Elimination of Racial and Ethnic Discrimination. This law subjects individuals and corporations to criminal and civil liability for acts of discrimination based on race, religion, or ethnicity. The punishment is higher if discrimination is conducted by a corporation than by individual.

\section{WHY BUSINESS SHOULD RESPONSIBLE FOR HUMAN RiGHTS?}

In response, advocates of corporate human rights responsibilities have argued. First, that corporations have a moral agency that is sufficiently appropriate to sustain moral 
responsibilities. If they can have other moral responsibilities, there appears no reason why they could not also have human rights responsibilities. Second, corporations have significant impacts on the individuals who work for them, their customers, the community, and the environment. Third, the hypothetical social contract view argues that corporations can be parties to a hypothetical or ideal social contract that calls for them to be responsible for human rights. Donaldson as well as Santoro hold such a view: the human rights responsibility of business is a special case of a corporation's general duty to exercise social responsibility: "The terms of the contract demand that [the corporation] honour rights as a condition of its justified existence." Finally, some argue that Transnational Corporations (TNCs) have, in fact, become political (and quasi-state) entities and so the concern that some have had regarding attributing human rights obligations to them is misplaced (George G Brenkert, 2016: 255-275).

Moreover, there are also several reasons why business should respect human rights; First, the UN Working Group on Business and Human Rights already encourages all states to develop, enact, and update a national action plan on business and human rights as part of the state responsibility to disseminate and implement the Guiding Principles. A second argument in favour of such an approach is that it favours policy coherence. The Guiding Principles strongly emphasize the need to ensure that companies face an incentive structure that encourages them to take into account their responsibility to respect human rights (and to act accordingly), rather than to circumvent such responsibility. Finally, a framework instrument is a tool to accelerate collective learning, and the gradual convergence on certain practices that, at the level of implementation, have proven their effectiveness (Olivier De Schutter, 2015: 56).

\section{The Implementation of Human Rights Audit In The FISHERY INDUSTRIES}

To show important Human Rights Audit is, the government of Indonesia implements Human Rights Audit in Fishery sector, by making regulations. There is full commitment from the government to make new regulation such as Ministerial Regulation on Human Rights System and Certification in the Fishing Industry No. 35/2015.

Human Rights Audit for Fishery Industries in Indonesia is conducted by using the obligation of each stakeholder to make an assessment referred to as Human Rights Certification.

The policy background are as follows:

A. Evidence of serious human rights violations in fishery business in Benjina and Ambon, Indonesia.

B. UN Guiding Principles on Business and Human Rights (2011) and ILO Convention No. 188 of 2007 which provide international guidance for countries to apply business and human rights \& responsible fisheries practices

C. Indonesia actually has ratified two major human rights covenants: CCPR and ECOSOC. namely:

Meanwhile, in the ministerial regulation there are 3 parts

A. Policy, Human Rights System in the Fishing Industry. 1. Human Rights Policy: commitment of fisheries business owners to respect human rights. 2. Human Rights Due Diligence: a process conducted by fisheries business owners to identify, to prevent, to mitigate, and to adequately address the impact of human rights violations. 3. Human Rights Remedy: process to resolve the human rights violations.

B. Certification of Human Rights in The Fishing Industry. This is a process to assess and ensure the compliance of fishing business owners to respect Human Rights through the implementation of Human Rights system in the fishing industry.

C. Failure to Comply. 1. Suspension or revocation on Fisheries licenses; 2. Recommendation to the Minister of Manpower to revoke labor utilization permit; 3. Public announcement (shaming) by the Minister of Marine Affairs and Fisheries in media.

Therefore, all stakeholders evolved in fishery industries in Indonesia must conduct Human Rights Audit based on the procedure:

A. Implementation of human rights on fisheries business by fisheries corporation

B. Corporations apply for certification assessment on fisheries human rights to the Fisheries Human Rights Team; by completing required documents.

C. Fisheries Human Rights Team appoint (accredited) assessment institution/ assessor.

D. Assessment of fisheries corporation

E. Publishment of human rights certificate.

\section{A. Opportunity For Fishery-Employment System Improvement}

Support better administration of the fisheries business licensing. Completing fishing license documents (SIUP, SIPI/SIKPI) for fishing vessel management business. Support better administration of national employment system (Sjarief Widjaja, 2017: 14):

\section{1) Fishing vessel crew documents}

a. Cooperation agreement

b. Participation for the unions labor

c. Fisher's Work Agreement (Work contract)

d. Insurance \& social assurance

e. Certificates of fishery competence

2) Completeness of employement document (for foreign workers); work visa, letters of recommendation.

\section{B. Certification of Fishing Vessel Crew}

There are some steps to audit for fishing vessel crew as follows (Sjarief Widjaja, 2017: 19):

1. Certification of Fish Handling Skill (Sertifikasi Keterampilan Penanganan Ikan/SKPI) and Competency of Fishing Gears. Goals: Crew can effectively operate 'environmental-friendly fishing gear' within CCRF rules (Code Of Conduct For Responsible Fisheries). Implenting Agency: MMAF in coordination with local fisheries department.

2. Facilitation of Crew's Protection and Document Implementation, Collecting Mou and SOP (Standard 
Operation Procedure) of Fishing Vessel Crew Document. Creating SOP of Fishing Vessel Crew Document.

3. Implementation of Working Agreement (Perjanjian Kerja Laut/PKL). Register the Fishing Vessel Crew Agent Corporate. Socialization Ministerial Regulation on Fisher's Work Agreement (42/PERMEN0KP/2016).

\section{REFERENCES}

[1] Adzkar Ahsini, et, all. (Ed). Business Relations and Human Rights; Context and Legal Perspective in Indonesia. Jakarta: Elsam and Faculty of Law Gadjah Mada University, 2016.

[2] Arnold, Denis G. Business and Human Rights Journal, 1 (2016), pp. 255-275.

[3] Brenkert, George G. Business and Human Rights Journal, 1 (2016), pp. 277-306.

[4] De Schutter, Olivier. Towards a New Treaty on Business and Human Rights. Business and Human Rights Journal / Volume 1 / Issue 01 / January 2016, pp $41-67$. s

[5] Getchell, Mark. International Organization for Migrants, Trafficking Persons in The Finshing Industry, Presented at international conference on Human Rights and Business in The Fishing Industries held by FIHRSST and Ministry of Ministry of Marine Affairs and Fisheries Republic of Indonesia, Monday, March 24, 2017.

[6] Institute for Policy Reseach and Advocacy. Corporate Responsibility to Respect Human Rights. Jakarta: Elsam, 2014.
[7] United Nations. Guiding Principles on Business and Human Rights: Implementing the United Nations 'Protect, Respect and Remedy' Framework. Human Rights Council Resolution 17/4, 16 Juni 2011.

[8] Reinisch, August. The Changing International Legal Framework for Dealing with Non-State Actors. Dalam Philip Alston, ed, 2004, Non State Actors and Human Rights, Academy of European Law, European University Institute in Collaboration with the Center for Human Rights and Global Justice, New York University Law School, Oxford University Press, Oxford.

[9] Santosa, Mas Achmad. Combating Transnational Organized Fisheries Crime and Human Rights Abuses in Indonesia Fishing Industry. Presented at international conference on Human Rights and Business in The Fishing Industries held by FIHRSST and Ministry of Ministry of Marine Affairs and Fisheries Republic of Indonesia, Monday, March 24, 2017.

[10] Soemitro, Ronny Hanitijo. Legal Research Methodology. Jakarta: Ghalia Indonesia, 1983.

[11] Soekanto, Soerjono. Introduction of Legal Research. Jakarta: University of Indonesia, 1986.

[12] Valerina, J.L.K. Methode of Legal Research Module, rev. ed. Jakarta: Faculty of Law University Indonesia, 2009.

[13] Widjaja, Sjarif. Human Rights Protection in Indonesian Fishing Industry. Directorate General of Fishing at the Ministry of Marine Affairs and Fisheries of the Republic of Indonesia. Presented at international conference on Human Rights and Business in The Fishing Industries held by FIHRSST and Ministry of Ministry of Marine Affairs and Fisheries Republic of Indonesia, Monday, March 24, 2017.

[14] Zachrie, Ridwan. Human Rights Impelementation in Fishing Industry, PT. Perikanan Nusantara (Persero). Presented at international conference on Human Rights and Business in The Fishing Industries held by FIHRSST and Ministry of Ministry of Marine Affairs and Fisheries Republic of Indonesia, Monday, March 24, 2017. 